\title{
Applications of Microbial Enzymes in Food Industry
}

\section{Sindhu Raveendran ${ }^{1 *}$, Binod Parameswaran!, Sabeela Beevi \\ Ummalyma',2, Amith \\ Abraham', Anil Kuruvilla \\ Mathew', Aravind \\ Madhavan ${ }^{3}$, Sharrel Rebello ${ }^{4}$ and Ashok Pandey ${ }^{5}$}

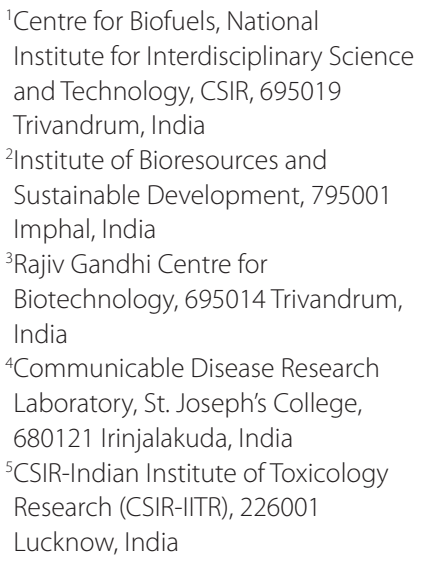

Received: August 29, 2017 Accepted: January 25, 2018

\section{${ }^{*}$ Corresponding author: \\ E-mail: sindhurgcb@gmail.com, sindhufax@yahoo.co.in \\ ORCID IDs: 0000-0002-7368-3792 (Raveendran), 0000-0001-7295-5509 (Parameswaran), 0000-0001-9667-025X (Ummalyma), 0000-0003-4228-3849 (Abraham), 0000-0002-5335-3382 (Mathew), 0000-0003-1224-2042 (Madhavan), 0000-0002-2381-5611 (Rebello), 0000-0003-1626-3529 (Pandey)}

Paper was presented at the 7th International Forum on Industrial Bioprocessing - IFIBiop 2017, May 21-24, 2017, Wuxi, PR China

\section{SUMMARY}

The use of enzymes or microorganisms in food preparations is an age-old process. With the advancement of technology, novel enzymes with wide range of applications and specificity have been developed and new application areas are still being explored. Microorganisms such as bacteria, yeast and fungi and their enzymes are widely used in several food preparations for improving the taste and texture and they offer huge economic benefits to industries. Microbial enzymes are the preferred source to plants or animals due to several advantages such as easy, cost-effective and consistent production. The present review discusses the recent advancement in enzyme technology for food industries. A comprehensive list of enzymes used in food processing, the microbial source of these enzymes and the wide range of their application are discussed.

Key words: enzymes, food industry, brewing, baking, juice clarification

\section{INTRODUCTION}

Microorganisms have been used in food fermentation since ancient times and fermentation processes are still applied in the preparation of many of the food items (1). Microbial enzymes play a major role in food industries because they are more stable than plant and animal enzymes. They can be produced through fermentation techniques in a cost-effective manner with less time and space requirement, and because of their high consistency, process modification and optimization can be done very easily (2). Many of these enzymes find numerous applications in various industrial sectors, e.g. amylolytic enzymes find applications in food, detergent, paper and textile industries (3). They are used for the production of glucose syrups, crystalline glucose, high fructose corn syrups, maltose syrups, etc. In detergent industry, they are used as additives to remove starch-based stains. In paper industry, they are used for the reduction of starch viscosity for appropriate coating of paper (4). In textile industry, amylases are used for warp sizing of textile fibres (4). Similarly, enzymes like proteases, lipases or xylanases have wide applications in food sectors. The following sections give detailed and updated information about various food enzymes of microbial origin. Table 1 (5-36) gives an overview of applications of microbial enzymes in food industry.

\section{a-AMYLASES}

a-Amylases (EC 3.2.1.1) are starch-degrading enzymes capable of hydrolyzing a-1,4 glycosidic bonds of polysaccharides, which results in the production of short-chain dextrins (37). These enzymes are widely distributed in all living organisms. Majority of a-amylases are metalloenzymes and require calcium ions for their activity, stability as well as integrity (38).

Wide applications of a-amylases in food industry include baking, brewing, starch liquefaction as well as a digestive aid (5). They are widely used in baking industry as flavour enhancement and antistaling agent to improve bread quality. During baking, a-amylases are added to the dough for conversion of starch to smaller dextrins, which are subsequently 
Table 1. Applications of microbial enzymes in food industry

\begin{tabular}{|c|c|c|}
\hline Microbial enzyme & Application & Reference \\
\hline a-Amylase & $\begin{array}{c}\text { Baking, brewing, starch liquefaction } \\
\text { Bread quality improvement } \\
\text { Rice cakes } \\
\text { Clarification of fruit juice }\end{array}$ & $\begin{array}{l}(5) \\
(6) \\
(7) \\
(8)\end{array}$ \\
\hline Glucoamylase & $\begin{array}{l}\text { Beer production } \\
\text { Bread quality improvement } \\
\text { High glucose and high fructose syrups }\end{array}$ & $\begin{array}{l}(9) \\
(10) \\
(10)\end{array}$ \\
\hline Protease & $\begin{array}{c}\text { Brewing } \\
\text { Meat tenderization } \\
\text { Coagulation of milk } \\
\text { Bread quality improvement }\end{array}$ & $\begin{array}{l}(11) \\
(11) \\
(11) \\
(12)\end{array}$ \\
\hline Lactase ( $\beta$-galactosidase) & $\begin{array}{l}\text { Lactose intolerance reduction in people } \\
\text { Prebiotic food ingredients }\end{array}$ & $\begin{array}{l}(13) \\
(14)\end{array}$ \\
\hline Lipase & $\begin{array}{l}\text { Cheese flavour development } \\
\text { Cheddar cheese production }\end{array}$ & $\begin{array}{l}(15) \\
(16)\end{array}$ \\
\hline Phospholipase & $\begin{array}{l}\text { Cheese flavour development } \\
\text { Production of lipolyzed milk fat }\end{array}$ & $\begin{array}{l}(17) \\
(17)\end{array}$ \\
\hline Esterase & $\begin{array}{c}\text { Enhancement of flavour and fragrance in fruit juice } \\
\text { De-esterification of dietary fibre } \\
\text { Production of short chain flavour esters }\end{array}$ & $\begin{array}{l}(18) \\
(19) \\
(20)\end{array}$ \\
\hline Cellulase & $\begin{array}{l}\text { Animal feed } \\
\text { Clarification of fruit juice }\end{array}$ & $\begin{array}{l}(21) \\
(22)\end{array}$ \\
\hline Xylanase & $\begin{array}{l}\text { Clarification of fruit juice } \\
\text { Beer quality improvement }\end{array}$ & $\begin{array}{l}(23) \\
(24)\end{array}$ \\
\hline Pectinase & Clarification of fruit juice & $(25)$ \\
\hline Glucose oxidase & $\begin{array}{l}\text { Food shelf life improvement } \\
\text { Food flavour improvement }\end{array}$ & $\begin{array}{l}(26) \\
(27)\end{array}$ \\
\hline Laccase & $\begin{array}{l}\text { Polyphenol removal from wine } \\
\text { Baking }\end{array}$ & $\begin{array}{l}(28) \\
(29)\end{array}$ \\
\hline Catalase & $\begin{array}{l}\text { Food preservation (with glucose oxidase) } \\
\text { Removal of hydrogen peroxide from milk prior to cheese production }\end{array}$ & $\begin{array}{l}(30) \\
(31)\end{array}$ \\
\hline Peroxidase & Development of flavour, colour and nutritional quality of food & $(32)$ \\
\hline a-Acetolactate dehydrogenase & Shortening maturation of beer & (33) \\
\hline Asparaginase & Reduction of formation of acrylamide during baking & (34) \\
\hline $\begin{array}{l}\text { Debittering enzymes - } \\
\text { naringinase }\end{array}$ & $\begin{array}{l}\text { Removal of bitter taste in fruit juice } \\
\text { Wine aroma enhancement }\end{array}$ & $\begin{array}{l}(35) \\
(36)\end{array}$ \\
\hline
\end{tabular}

fermented by yeast. It improves the taste, crust colour and toasting qualities of bread (6).

a-Amylases are also used in the manufacture of high-molecular-mass branched dextrins. They are used as a glazing agent for the production of rice cakes and powdery foods (7). In starch industry, they also find application for starch liquefaction, which converts starch into glucose and fructose syrups. Enzymatic conversion of starch involves three steps: gelatinization, liquefaction and saccharification. Gelatinization involves formation of a viscous suspension by dissolution of starch granules. This is followed by a liquefaction process, which reduces viscosity and involves partial hydrolysis. Glucose and maltose are further produced by saccharification. This requires highly thermostable enzymes and most of the starch saccharification is carried out with a-amylases from Bacillus amyloliquefaciencs, Bacillus stearothermophilus or Bacillus licheniformis (6).
For the production of ethanol, starch is converted to fermentable sugars by the action of a-amylases and further fermentation of the sugars to alcohol is carried out by Saccharomyces cerevisiae. Other applications of a-amylases include clarification of fruit juices, which is carried out in the presence of cellulases and pectinases to improve yield as well as to make the process cost-effective $(8,39)$.

\section{GLUCOAMYLASES}

Glucoamylases (EC 3.2.1.3) are exo-acting enzymes which catalyze the hydrolysis of polysaccharide starch from the non-reducing end, releasing $\beta$-glucose. They are also called saccharifying enzymes and are widely distributed in all living organisms. These enzymes are produced mainly by Aspergillus niger and Aspergillus awamori, but the one produced by Rhizopus oryzae is widely used for industrial applications (40). 
Majority of glucoamylases are stable at low temperature. At higher temperatures, they lose activity due to conformational change. Glucoamylases find wide range of applications in food industry, such as for the production of high-glucose syrups and high-fructose syrups. They also find application in baking industry to improve flour quality, reduce dough staling, as well as to improve bread crust colour and the quality of high fibre baked products (10). Glucoamylases convert the starch present in the flour to maltose and fermentable sugars. Fermentation by yeast leads to dough rise. These enzymes are also used for the production of glucose, which upon fermentation with Saccharomyces cerevisiae yields ethanol. Glucoamylases play an important role in the production of sake and soya sauce, as well as in the production of light beer. They metabolize dextrins and convert them to fermentable sugars with reduced calorific value and alcohol content in the beer (9).

\section{PROTEASES}

Proteases are enzymes which catalyze the hydrolysis of peptide bonds present in proteins and polypeptides. They are widely used in detergent and pharmaceutical, followed by food industries. They represent $60 \%$ of industrial enzymes on the market (41). The global demand for protease enzyme market has been growing at a compound annual growth rate (CAGR) of $5.3 \%$ during the period 2014-2019. Their demand is expected to increase much further as they find applications in leather processing as well as bioremediation processes. Proteases can be classified based on their origin, catalytic activity and nature of the reactive group in the catalytic site. The major sources of protease enzymes are animals, plant and microorganisms (both bacterial and fungal). Proteases are divided into two groups: exopeptidases and endopeptidases, based on the site of action on polypeptide chains (42). The exopeptidases act on the ends of polypeptide chains and endopeptidases act randomly in the inner regions of polypeptide chains. The endopeptidases are further classified into six groups, based on the catalytic residue present in the active site: serine, aspartic, cysteine, metallo, glutamic acid and threonine protease (43). Plant proteases such as bromelain, ficin and papain are widely used in food industry for various applications such as brewing, tenderization of meat, coagulation of milk and as a digestive aid (44). In addition, proteases are also used to improve the flavour, nutritional value, solubility and digestibility of food proteins as well as to modify their functional properties including coagulation and emulsification (11). Proteases are widely used in baking industry for the production of bread, baked foods, crackers and waffles. These enzymes are used to reduce the mixing time, decrease dough consistency and uniformity, regulate the gluten strength in bread and to improve the texture and flavour $(12,45)$. The acid protease from Aspergillus usamii has been successfully employed for the improvement of functional properties of wheat gluten (46). The addition of protease could release sufficient peptides and amino acid levels in the wort to get a proper fermentation. Acidic fungal proteases are used in improving fermentation of beer as they are efficient even at low $\mathrm{pH}$ by balancing the amino acid profile of beer (47). Another major application of proteases is associated with dairy industry (48). Naturally occurring proteases contribute significantly to the flavour characteristics of cheese. They are used for the acceleration of cheese ripening, to modify the functional properties and reduce the allergenic properties of milk products (48). In cheese making, proteases are also used to hydrolyze the specific peptide bond to generate paracasein and macropeptides (49).

\section{LACTASE ( $\beta$-GALACTOSIDASE)}

Hydrolysis of lactose is an important biotechnological process in food industry (50). The enzyme $\beta$-galactosidase catalyzes the hydrolysis of lactose. It belongs to the family of hydrolases. $\beta$-Galactosidase can be obtained from numerous biological systems including plants, animals and microorganisms (51). The production of $\beta$-galactosidase from microorganisms such as bacteria, fungi and yeast is a preferred choice due to higher yield and thus relatively low cost of the enzyme (13,52). The choice of source depends on the final application of the enzyme $\beta$-galactosidase, e.g. $\beta$-galactosidase from yeasts with $\mathrm{pH}$ optima of 6.5-7.0 is generally used for the hydrolysis of lactose in milk of whey. In the case of acidic whey hydrolysis, fungal $\beta$-galactosidase with $\mathrm{pH}$ optima of 3.0-5.0 is suitable. Thus the selection of $\beta$-galactosidase depends on the final application of the enzyme or industry $(53,54)$. $\beta$-Galactosidase produced from yeast Kluyveromyces lactis requires ions such as $\mathrm{Mn}^{2+}$ or $\mathrm{Na}^{+}$, whereas Kluyveromyces fragilis requires $\mathrm{Mn}^{2+}, \mathrm{Mg}^{2+}$ or $\mathrm{K}^{+}(55)$.

In industrial applications, two major classes of $\beta$-galactosidase are of prime importance. They are cold-active and thermostable $\beta$-galactosidase $(56,57)$. On commercial scale, $\beta$-galactosidase is produced using microorganisms with GRAS status for their application in milk and dairy products. Lactase is used with milk and milk-based products to reduce lactose intolerance in people. The scoopability and creaminess of ice creams improved significantly after the hydrolysis of lactose with lactase (50). Additional advantage of hydrolyzing lactose into monomers is the reduction requirement of sweeteners as they could improve the sweetness of the products $(13,58)$. Another major application of lactase is the lactose hydrolysis in whey. Whey is a byproduct of cheese production and its main components are lactose, proteins and minerals. This causes critical environmental issues associated with dairy industry as lactose is associated with high biological oxygen demand (BOD) and chemical oxygen demand (COD) $(59,60)$. Another application of lactase is the formation of galactooligosaccharides (GOS) from lactose hydrolysis due to transglycosylation activity of $\beta$-galactosidase. The GOS could be used as prebiotic food ingredients (14).

\section{LIPASES}

Lipases are enzymes which catalyze the hydrolysis of long-chain triglycerides. They are naturally present in the stomach and pancreas of humans and other animal species in order to digest fats and lipids (61). Microbial lipases are produced by 
bacteria, fungi and yeast. Microbial enzymes contribute to approx. $90 \%$ of global lipase market (62). This enzyme finds application in various industries including food, biofuel, detergents and animal feed. It is also used in leather, textile and paper processing applications (63). In the food and beverage industry, lipases find major application in dairy, baking, fruit juice, beer and wine industries. Although it finds many applications in various industries, the market share of lipase is less than $10 \%$ of global industrial enzyme market (62).

Commercial lipases are mainly used for flavour development in dairy products and processing of other foods containing fat (16). They can improve the characteristic flavour of cheese by acting on the milk fats to produce free fatty acids after hydrolysis (15). Different types of cheese can be made by using lipases from various sources, e.g. Romano cheese using kid/ lamb pre-gastric lipase, Camembert cheese using lipase from Penicillium camembertiand cheddar cheese using Aspergillus niger or A. oryzae (16). Lipase catalysis could improve the texture and softness of cheese. Lipases are also used as flavour development agents in butter and margarine, also to prolong the shelf life of various baking products (16). In alcoholic beverages such as wine, the aroma can be modified using lipase. They are used to improve the quality of cocoa butter, which has a melting point of $37^{\circ} \mathrm{C}$ due to the presence of palmitic and stearic acids and can easily melt at $37^{\circ} \mathrm{C}(64,65)$. A patent has been filed by Unilever using immobilized Rhizopus miehei lipase, which can replace palmitic with stearic acid to give desired stearic-oleic-stearic triglyceride (64-66). Functionalized phenols were esterified for the synthesis of lipophilic antioxidants for the application in sunflower oil using immobilized lipase from Candida antarctica (CALB), Candida cylindracea Ay30, Helvina lanuginosa, Pseudomonas sp. and Geotrichum candidum. Lipases also find application as a biosensor in food industry. Immobilized lipase was successfully used for the determination of organophosphorous pesticides with a surface acoustic wave impedance sensor by lipase hydrolysis (67). It may also be used in the determination of triglycerides and blood cholesterol if the lipase is immobilized onto $\mathrm{pH}$ /oxygen electrodes in combination with glucose oxidase (68). Microbial lipases such as lipase from Candida rugosa have many applications which cannot be met by chemical synthesis. This lipase finds application in the production of ice cream, single-cell protein, carbohydrate esters and amino acid derivatives (16). In addition to this, lipase could also be used in the processing of different waste streams that are released from food industries (69).

\section{PHOSPHOLIPASES}

Phospholipases selectively break down phospholipids into fatty acids and other lipophilic substances. They can be divided into four major classes (A, B, C and D) based on their mechanism of action (70). Phospholipase A1 (PLA1), phospholipase A2 (PLA2), and phospholipase B act on the carboxylic ester bonds of phospholipids, thus displacing and replacing the acyl group chain through various chemical reactions like hydrolysis, esterification and transesterification.
Phospholipases C (PLC) and D (PLD), which modify polar head group, are also known as phosphodiesterases, and they recognize the phosphodiester linkage (70). Phospholipases are widely used in food industry, most importantly in the production of oils, dairy industry and in the manufacture of several bakery items (71). They also find applications in the degumming of various vegetable oils, cheese manufacture and bread manufacture (71). Phospholipase from Fusarium oxysporum is a commercially available phospholipase which has both phospholipase and lipase activities and it is marketed by Novozymes A/S (Denmark) for baking application under the name LipopanF ${ }^{\circledR}$ (71). The PLA2 commercialized by DSM Food Specialties (The Netherlands) with the trade name Maxapal ${ }^{\circledR}$ A2 has been reported by Zhao et al. (72), who described that the egg yolk treatment with PLA could increase the stability of dough and interaction of starch and gluten. Another commercial phospholipase in baking industry is LysoMax ${ }^{\circledR}$ product (DSM Food Specialties), which is made up of a bacterial strain, specifically acting on lecithin (73). Phospholipases are also used in the processing of various dairy products to enhance the stability of fat or maximise the yield of cheese, milk, butter and ice cream (71). The important applications of lipases include enhancing the cheese flavour, lipolyzed milk fat production for use in butter as flavour, etc. (17).

\section{ESTERASES}

In aqueous solution, esterases are able to facilitate the splitting of esters into acid and alcohol. In addition to this, esterases hydrolyze short-chain rather than long-chain acylglycerols, thus being different from lipases. Esterases play a prominent role in the food industry and alcoholic beverage industries, where they have been mostly used for the modification of oil and fat in various fruit juices and to produce fragrances and flavours (18). Feruloyl esterases, an important group of enzymes from esterase family, break the ester bond between ferulic acid and different polysaccharides in plant cell wall. Since feruloyl esterases hydrolyse lignocellulosic biomass, they are inevitable for waste management (19).

Cheng et al. (74) screened for feruloyl esterase activity in a metagenomic library obtained from the microbial population of a cow rumen and identified a protease-resistant feruloyl esterase, which can release ferulic acid from wheat straw. This particular esterase has great commercial application because of its high $\mathrm{pH}$ and thermal stability and protease resistance.

In cheese manufacture, the fruity flavours are the result of different methyl or ethyl esters of short-chain fatty acids. Bacterial production of ethyl esters and thioesters has been reported. Alvarez-Macarie and Baratti (20) reported the production of a novel thermostable esterase from the highly thermotolerant Bacillus licheniformis heterologously expressed in E. coli for the production of short-chain flavour esters. Feruloyl esterase is a key enzyme in the biosynthesis of ferulic acid, which is the precursor for vanillin, an aroma compound used in foods and beverages (75). Several researchers have reported the microbial production of ferulyl esterase $(76,77)$. 


\section{LIPOXYGENASES}

Lipoxygenases (LOX) are involved in the dioxygenation of polyunsaturated fatty acids in lipids containing a cis-1,4-pentadiene. They contain single polypeptide chain which is further assembled into an N-terminal domain and the catalytic $\beta$-barrel domain. LOX enzymes are non-haem iron-containing enzymes. The LOX-catalyzed reaction produces different precursors for the production of different volatile and aroma-producing chemical substances in plants. LOXs are used in aroma generation in food industry and also in bread making (78). Soya bean lipoxygenases (LOX) is the most studied lipoxygenase enzyme. Bacterial LOXs possess different specificity towards fatty acids. LOX from Nostoc sp. oxygenates at specific site in linoleic acid, but the LOX from Anabaena sp. exhibits variable specificity (79-82).

The main applications of LOXs in dough are based on their ability to bleach the flour pigment carotenoid, by co-oxidation of the pigment with fatty acids $(83,84)$. Lipoxygenases are also employed to improve tolerance to mixing and different handling properties of dough (78). This effect is due to the oxidation of thiol group in gluten, which may lead to redistribution of different disulphide bonds, tyrosine cross-linking and subsequent strengthening of the gluten. This also leads to the improvement in dough rheology. Recently Patel et al. (85) purified lipoxygenase from Lasiodiplodia theobromae by different chromatography techniques and fully characterized the enzyme. L. theobromae was reported to contain two types of lipoxygenases with molecular mass of 93 and $45 \mathrm{kDa}(86)$.

\section{CELLULASES}

Cellulases are enzymes that act on polymeric cellulose and hydrolyze $\beta-1,4$ linkages to liberate glucose units. The three major classes of cellulases are endo-(1,4)- $\beta$-D-glucanase (EC 3.2.1.4), exo-(1,4)- $\beta$-D-glucanase (EC 3.2.1.91) and $\beta$-glucosidases (EC 3.3.1.21) (87). The catalytic modules of cellulases belong to glycosyde hydrolase (GH) family and have been classified in different groups based on differences in amino acid sequences and three-dimensional structural features. GH family enzymes mainly use acid-base catalysis mechanism for cleaving glycoside bonds in cellulose. The catalysis is achieved by two major residues (a proton donor and a nucleophile) of the enzyme in the active site region (88). The hydrolysis occurs via retention or inversion mechanism depending on the spatial position of these catalytic residues in the enzyme. Endoglucanases cleave $\beta-1,4$-bonds in amorphous region of cellulose and expose the non-reducing and reducing ends of cellulosic polymer. Endoglucanases from various sources belong to different glycoside hydrolase families, among which the major are 5-9, 12, 44, 45, 48,51 and 74. Most of the fungal endoglucanases contain a catalytic module with carbohydrate-binding module (CBM), but catalytic module without CBM was also reported from fungal species (89). Multiple catalytic modules and CBMs are present in bacterial endoglucanases. A cleft/grove-shaped active site is present in the catalytic module of most of the endoglucanases
(90). Exoglucanases or cellobiohydrolases (CBHs) act on available reducing or non-reducing ends of cellulose polymer and liberate cellobiose. Fungal and bacterial $\mathrm{CBH}$ s show diversity in catalytic module and belong to glycoside hydrolase families 5 , $6,7,9,48$ and 74 (91). A tunnel-shaped catalytic module is observed in most of the $\mathrm{CBHs}$. $\beta$-Glucosidases catalyze the final step in cellulose breakdown by cleaving the non-reducing terminal $\beta$-D-glucosyl residues and removing $\beta$-D-glucose (92). The catalytic modules belonging to glycoside hydrolase families 1, 3 and 9 are reported from various $\beta$-glucosidases. The cellulolytic machinery of microbes is mainly regulated through feedback inhibition of b-glucosidases by their reaction product glucose. The major difference from $\mathrm{CBH}$ s is the absence of $\mathrm{CBM}$ in their structure. A pocket-shaped active site region of $\beta$-glucosidases helps them to attach the glucose molecule to non-reducing end and release glucose unit from cellodextrins or cellobioses (90). A large diversity of microorganisms is reported to produce cellulases during their growth on cellulosic materials. The industrial making of cellulases is mainly from microbial sources, bacteria and fungi, and these microorganisms can be diverse in their habitat. The aerobic bacteria show similar mechanism of cellulose degradation to that of aerobic fungi. In anaerobic bacteria, cellulosomes are located on the cell surface and operate via a different system. Cellulases from fungi (Aspergillus and Trichoderma) and bacteria (Bacillus and Paenibacillus) are potentially used in the production of food. They are also widely used for various industries such as textile, paper, detergent and food industry (21). In juice industry, cellulases are applied in combination with other macerating enzymes for increasing process performance and yield, improving the extraction methods, clarification and stabilization of juices (22). They can also reduce the viscosity of nectar and puree from fruits such as apricot, mango, plum, papaya, pear and peach, and are used for the extraction of flavonoids from flowers and seeds. The preferences of cellulase-mediated extraction over conventional methods are due to higher yield, less heat damage and short processing time. Cellulases are utilized for the extraction of phenolic compounds from grape pomace (93). $\beta$-Glucosidases in combination with pectinase alter the structure, flavour and aroma of fruits and vegetables (94). They are also reported to reduce bitterness of citrus fruit and improve aroma and taste (95). Cellulases are used with other enzymes for efficient olive oil extraction (96). In wine production, cellulases are used in combination with other enzymes to increase yield and quality (97). The main advantages of using these enzymes are improved maceration, better colour development, must clarification and finally wine stability and quality (98). Studies of Oksanen et al. (99) showed that cellulases can significantly reduce wort viscosity. The aroma of wines can be improved by $\beta$-glucosidases through modifications of glycosylated precursors.

\section{XYLANASES}

Xylanases are produced by microorganisms to cleave $x y-$ lans, a major constituent of hemicellulose. Three major enzymes, endoxylanases, exoxylanases and $\beta$-xylosidases, act 
synergistically and are required for the breakdown of xylan backbone in hemicellulose. Endoxylanases (EC 3.2.1.8) cleave the $\beta-1,4$ bonds of xylan backbone. Exoxylanases (EC 3.2.1.37) hydrolyse $\beta-1,4$ bonds of xylan from the non-reducing ends and release xylooligosaccharides. $\beta$-Xylosidases cleave the xylobiose and xylooligosaccharides to release xylose (100). The major functions of xylanases are performed by a catalytic module and few classes possess an additional CBM for binding to substrates. The two major catalytic modules of hemicellulases are glycoside hydrolases (GHs) and carbohydrate esterases (CEs). Endoxylanase hydrolyses the xylan backbone and has catalytic cores belonging to $\mathrm{GH}$ families 8, 10, 11, 30 and 43 with the most common ones being GH 10 and 11 (101). These differ in their substrate specificities and the GH10 is more active on substituted xylan. Similar to cellulases, they may also contain CBMs (102). Exoxylanases randomly cleave the xylan backbone from inside, releasing long chain xylooligomers on which the $\beta$-xylosidases act. The catalytic module of these enzymes belongs to the $\mathrm{GH}$ families 3, 30, 39, 43, 52 and 54 . These two enzymes are often collectively called xylanases. $\beta$-Xylosidase or xylan-1,4- $\beta$-xylosidase act on the xylooligosaccharides and xylobiose to release xyloses (103).

Xylanases are produced by microbes like actinomycetes, bacteria and fungi. The major actinomycete and bacterial species producing xylanase are Streptomyces sp., Bacillus sp. and Pseudomonas sp. (104-106). Those produced by bacteria and actinomycetes are effective in a broader range of $\mathrm{pH}$ (5.0-9.0), with the optimum temperature for xylanase activity between 35 and $60{ }^{\circ} \mathrm{C}$. Fungi are major sources of xylanase due to their high content and extracellular release of the enzyme (107). The major fungal species producing xylanase are Aspergillus sp., Fusarium sp. and Penicillium sp. Fungal xylanases have higher activity than bacteria or yeast (108).

Carbohydrate-hydrolyzing enzymes are usually used in bread making industry. Rheological properties of dough are improved through enzymatic hydrolysis of non-starch polysaccharides (109). Xylanases are widely used in bread making industry with other enzymes. The potential effectiveness of xylanolytic enzymes increases its use in bread making. They can increase the specific bread volume and this improves the quality of bread. The hemicellulose in wheat flour is broken down by xylanase, which increases the binding of water in the dough. The dough becomes softer and crumb formation is delayed, allowing the dough to grow (108). Xylanase is used to improve texture, tastiness and palatability in biscuits. They also play an important role in juice production by improving extraction, clarification and stabilization (23). In combination with other enzymes, xylanases lead to better yield of juice and increased recovery of aromas, essential oils, vitamins, mineral salts, pigments, etc. (110). In beer making industries, xylanases are used for hydrolysing the cellular wall of barley. Hydrolysis leads to release of arabinoxylans and lower oligosaccharides, which reduces the muddy appearance and viscosity of the beer (24).

\section{PECTINASES}

Pectinases are enzymes which catalyze the hydrolysis of glycosidic bonds in pectic polymers. Pectic substances found in tomato, pineapple, orange, apple, lemon pulp, orange peel and other citrus fruits act as natural substrate for this enzyme. Functionally pectinases can be categorized as polygalacturonases (which hydrolyse glycosidic a-(1-4) bonds), pectin esterases (which remove acetyl and methoxyl groups from pectin), pectin lyase and pectate lyase (111). Pectinases can be produced from natural as well as recombinant microbes with attempts made to increase their thermostability and yield (112). Pectinases can also act either on smooth or hairy regions of pectin (113). Based on $\mathrm{pH}$, there are acidic and alkaline pectinases also grouped in endopectinases when enzyme cleaves randomly, and exopectinases when the terminal ends are targeted.

Pectinases find a multitude of industrial applications such as in paper bleaching, food industry, remediation, etc. (25). Juices with added pectinase have a clearer appearance and filterability than enzyme-depleted counterparts (111). Apart from reducing the turbidity and haze generation of naturally derived fruit juices such as apple and banana, pectinases also improve the colour and flavour of drinks $(113,114)$. The addition of gelatin and pectin greatly increases the viscosity and turbidity of juices, and removal of the haze is the most costly part of juice production. The use of biogenic enzymes such as pectinases in juices would act almost nine times better than mechanical maceration to get good results.

\section{GLUCOSE OXIDASE}

Glucose oxidase (EC 1.1.3.4) belongs to a large group of enzyme family called oxidoreductases. Glucose oxidase is a flavoprotein discovered in 1928 by Müller (115). He stated that in the presence of dissolved oxygen the enzyme can convert glucose to gluconic acid. In the reaction, $\beta$-D-glucose is oxidised to gluconolactone and molecular oxygen is reduced to hydrogen peroxide. The glucanolactone is then spontaneously hydrolysed to gluconic acid (116). The enzyme is homodimeric and contains two similar polypeptide chain subunits $(80 \mathrm{kDa})$. The subunits are covalently linked by disulphide bonds and one flavin adenine dinucleotide (FAD) molecule non-covalently bound to active site region of each subunit. The glucose oxidase production has been reported from various microorganisms and it was first discovered in Aspergillus niger and Penicillium glaucum. Aspergillus niger species is widely used for production of glucose oxidase and its strains can produce higher amount of glucose oxidase (117). Penicillium adametzii is a widely used fungus for the production of extracellular glucose oxidase (118). The different bacterial species are also reported to produce glucose oxidase. Although many species of bacteria and fungi are reported to produce this enzyme, fungi are considered for the industrial production of glucose oxidase (119).

Glucose oxidase has its wide use in various industries like pharmaceutical and food industries, and in biofuel cells (26). 
Its use is increasing in baking industry because its oxidizing effects make stronger dough (27). In food industry, it enhances the flavour, aroma and stability of food products by removing glucose and oxygen from diabetic drinks and egg white (27). Glucose oxidase improves the colour, texture, flavour and shelf life of food products and prevents rottening (27). During food packaging glucose oxidase is used for increasing storage life by removing oxygen (27).

\section{LACCASE}

Laccases (EC 1.10.3.2) are a cluster of oxidases which represent the largest subgroup of multicopper enzymes. Commonly known as blue oxidases, they are used for studying their potential to oxidize phenolic compounds and therefore applied in several industrial sectors (120-122). These enzymes act as a potent biocatalyst for application in chemical synthesis, biobleaching of paper pulp, bioremediation, biosensing, wine stabilization and textile finishing. They have different specificity for substrate and a wide range of oxidizable substrates, which further depends on the type of microbial sources producing the enzyme (121). Laccases catalyze the oxidation of a wide range of compounds such as phenolics, aromatic amines and ascorbate $(120,121)$. These enzymes combine reducing substrate having four oxidized electrons with four reduced electrons for cleaving dioxygen bond in the presence of four copper atoms present in laccases (120). The mechanism of catalytic activity of laccase is described in the report of Madhavi and Lele (121) and Morozova et al. (122).

Laccases are secreted extracellularly by several fungi as a product of their secondary metabolism during fermentation, but their production is limited to a few fungal species (122). Well known producers of laccases belong to Deuteromycetes, Ascomycetes and Basidiomycetes $(123,124)$. Funalia trogii is a white rot fungus capable of producing laccase through absorbent fermentation. The maximum laccase production by F. trogii reached $11900 \mathrm{U} / \mathrm{L}$, which was 4.97 times higher than that of normal fermentation (125). Bacillus licheniformis produces recombinant laccases for industrial applications (126). Recently, heterologous expressions have been used for laccase production. Bacillus vallismortis fmb-103 genes were cloned and heterologously expressed in Escherichia coli BL21 (DE3) cells (127).

Laccase is used for modification of colour appearance of food and beverage industries, or for wine stabilization as an alternative to physical and chemical adsorbents. Removal of polyphenols from wine should be chosen to avoid adverse changes in wine organoleptic characteristics including stability in acidic medium and reversible inhibition due to the presence of sulphite (28). Furthermore, this enzyme is used in cork stopper manufacturing industry (128).

Haze formation is one of the problems in brewing industry. To avoid it, laccases have been applied for polyphenol oxidation as substitute for traditional approach by different researchers (129-131). This enzyme is also used for oxygen removal in the final step of beer production which prolongs the storage life of beer. Commercial laccase called Flavourstar, manufactured by Novozymes, is used for removing the off-flavour formation in brewing industry (132). It is used in baking because it has the capability to cross-link with biopolymers. The application of laccase in baking enhances stability, strength and decreases stickiness which further increases machinability of bread batter. Moreover, it increases volume and enhances softness of the product as reported by Labat et al. (29) and Si (133).

\section{CATALASE}

Catalase (EC 1.11.1.6) is a tetrameric protein found in aerobic organisms. It helps hydrogen peroxide decomposition. This enzyme can be produced from microbial sources such as Aspergillus niger and Micrococcus luteus and from bovine liver. Microorganisms are usually preferred as sources for enzyme production due to their advantages such as fast growth, easy handling and genetic tuning for obtaining a desired product $(134,135)$. The anaerobic Bacteroides fragilis exhibited increased catalase levels in media with haem (136). Frankenberg et al. (137) isolated catalase from Enterococcus faecalis, which completely depends on haem source without which it cannot synthesize porphyrin group. A facultative anaerobic catalase-producing Bacillus maroccanus resistant to hydrogen peroxides was isolated from textile effluents (138). A potent catalase-producing bacterium Pyrobaculum calidifontis was isolated from hot springs in Los Banos and Calamba, Laguna, Philippines (139). A thermo-alkaliphilic catalase-positive strain of Bacillus halodurans LBK 261 was isolated from alkaline hot-spring waters of Kenya (140). A halo(alkali) tolerant catalase-producing Oceanobacillus oncorhynchi ssp. incaldaniensis was isolated from an algal mat capable of producing catalase at wide range of $\mathrm{pH} 6.0-9.5$ and salinity of 5-20\% (141). A catalase-positive psychrophile Bacillus N2a was isolated from seawater (142). Other catalase-positive bacteria such as Rhizobium radiobacter were isolated from industrial effluent from beverage industry (143), Comamonas testosteroni and C. terrigena from effluent sludge enriched with crude oil along with heavy metals (144) and Serratia SYBC08 from hydrogen peroxide sludge (145). Psychrobacter piscatorii T-3, a psychrotolerant bacterium isolated from bleach-rich runoff, has high catalase activity (146). Fungi and yeast are able to produce catalase. The highest level of catalase activity of $400 \mathrm{mg} / \mathrm{g}$ was observed in isolates of Aspergillus niger (144). A catalase-positive entomopathogenic fungus Metarhizium anisopliae strain Ma10 (CNRCB MaPL10) was isolated from Geraeus senilis (147).

In fabric industry, catalase is used for removing excess hydrogen peroxide from fabric. This enzyme is mostly used along with other enzymes in food processing industry. Catalase is often used with glucose oxidases for food preservation. Ough (30) used a glucose oxidase/catalase cocktail for elimination of oxygen from wine before bottling and evaluated the formation of acetaldehydes. Results showed that colour and amount of acetaldehyde were stable if treated properly with enzymes (148). Catalase is applied in milk processing industry to eliminate peroxide from milk (31), to remove glucose from egg white 
in baking industry and in food wrappers to prevent oxidation and control perishability of food. This enzyme has limited use in cheese production.

\section{PEROXIDASE}

Peroxidases (EC 1.11.1.7) are oxidoreductase proteins that contain iron(III) protoporphyrin IX as the prosthetic group. They catalyse the reduction of peroxides and oxidation of a wide range of inorganic and organic compounds. Their molecular mass ranges from 30000 to $150000 \mathrm{Da}$, and they comprise a group of unique enzymes such as iodide peroxidase, NADH peroxidase and glutathione peroxidase as well as a group of other nonspecific enzymes (149). Peroxidases are present in plants, microorganisms and animals. They are involved in lignification processes in plants (150) and defence mechanisms against damaged or infectious tissues (151).

Among microorganisms, Phanerochaete chrysosporium is the best characterized peroxidase-secreting organism (152). Industrial scale applications of fungal peroxidases are limited by challenges associated with post-translational modification of proteins (153). However, bacterial peroxidases are easier to produce and have better stability and activity suitable for industrial applications. These enzymes are applied with bacterial laccases for dye decolourization (154). Peroxidase activities are reported in bacterial taxa, such as Firmicutes, Proteobacteria, Actinobacteria and Acidobacteria $(155,156)$. Moreover, actinomycetes, which are soil bacteria, are able to grow like fungi and have similar ecological niche, and can produce peroxidases for lignin degradation $(154,157)$. The first secreted extracellular lignin peroxidase was produced by Streptomyces viridosporus T7A (158).

Peroxidase catalyzes a wide range of substrates using hydrogen peroxide or other peroxides (159). This enzyme is used in food industry for producing flavour, colour and texture and improving nutritional quality of food. Other applications include as biosensors, in polymer synthesis and in the management of pollutants in the environment (160). It can be used for treating phenolic effluents from industries. Thermal inactivation of peroxidases is used in food industry to measure the efficiency of blanching treatment, which further enhances the shelf life of food (32). The negative effect of peroxidases is that they cause undesirable browning of fruits and off-flavours of vegetables.

\section{a-ACETOLACTATE DECARBOXYLASE}

a-Acetolactate decarboxylase greatly aids in the fast maturation of beer (161). This enzyme can be produced from natural microbes such as Brevibacillus brevis (162) or from recombinant Saccharomyces cerevisiae (163). The enzyme catalytically converts acetolactate to acetoin via a two-step reaction involving direct decarboxylation of substrate to an enol derivative and its further protonation to final product (162).

Enzyme-based removal of a-acetolactate and a-aceto-a-hydroxybutyrate assists in overcoming the rate-limiting step of beer maturation. While the maturation of beer without the use of enzymes takes 2 to 12 weeks (33), the use of a-acetolactate decarboxylase results in maturation within 24 hours depending on the source of enzyme. Moreover, the off-taste due to the presence of diacetyl in beer is nullified by the action of this enzyme. Studies indicate that both free and encapsulated form of this enzyme work efficiently in the process, thus aiding the use of immobilized enzymes at reduced costs (163). Novel inorganic nanoflowers or alginate microbeads immobilized with a-acetolactate decarboxylase are promising strategies with better thermal stability, reusability and catalytic efficiency (164).

\section{ASPARAGINASE}

Of the various microbially derived enzymes, asparaginases form a major class of pharmaceutical, nutraceutical and industrially significant enzymes widely used by man (165). Asparaginase, as the name implies, catalyses the breakdown of the asparagine to subsequent acid derivative aspartic acid and $\mathrm{NH}_{3}$ and can be considered as the asparagine-depleting enzyme. Asparagine is a nonessential amino acid to humans, whereas it is an essential amino acid for cancerous cells. Thus, the depletion of asparagine critically affects the growth of cancerous cells, which forms the basis of this enzyme as anticancer agent (165).

Various food processing methods such as frying in oil and baking cause the conversion of asparagine to acrylamide, a known carcinogen. Among various methods attempting to overcome the acrylamide formation, the depletion of asparagines by enzymatic treatment has been found effective in reducing the formation of acrylamides from asparagines by $97 \%$ (34).

\section{DEBITTERING ENZYMES - NARINGINASE}

Naringinase (EC 3.2.1.40) is mainly responsible for the breakdown of naringin, the principle bitter flavanone glycoside found in citrus fruits (166). Naringin is broken down to a glycon naringenin and rhamnose as a result of its $a$-rhamnosidase and $\beta$-glucosidase action. Nariginase is produced mostly by fungal isolates, viz. Aspergillus niger, Circinella, Eurotium, Fusarium, Penicillium, Rhizopus and Trichoderma and bacteria such as Bacillus sp., Burkholderia cenocepacia, Bacteriodes distasonis, Thermomicrobium roseum, Pseudomonas paucimobilis, etc. (167). Fungal sources of naringinase are found to be more predominantly used than the bacterial ones due to increased yield.

Naringinase has a major role in food processing as a debittering enzyme supplemented to fruit juices. Both free (35) and immobilized forms of this enzyme are used to get better results. Immobilization of this enzyme has been done in a variety of substrates such as polyvinyl alcohol cryogels (168), packaging films (169), cellulose triacetate nanofibre (170), graphene (171), etc. Various food additives such as biopolymers and sweeteners can be synthesized using rhamnosidase or naringinase. Yet, another use of naringinase together with $\beta$-glucosidase and arabinosidase is to improve the aroma of wine (36). The use of naringinase is also noted in tomato pulp preparation, kinnow peel waste treatment and prunin preparation (167). 


\section{CONCLUSIONS AND FUTURE PERSPECTIVES}

Enzymes find application in food, detergent, pharmaceutical and paper industries. Nowadays, the enzymatic hydrolysis and enzyme-based processes are preferred to the chemical ones due to the environmentally friendly nature, efficient process control, high yield, low refining costs and process safety. In comparison with plant and animal enzymes, microbial enzymes can be produced very effectively by different fermentation techniques like solid-state and submerged fermentations. It is also easy to produce microbial enzymes on a large scale. The microbial enzymes can be easily modified through various molecular and biochemical approaches. Hyperproduction of microbial enzymes with high specific activity can be achieved by overexpression of their genes. Many of the enzymes of microbial origin are still unexplored and there are many opportunities for finding wider industrial application of microbial enzymes, especially in food sector.

\section{ACKNOWLEDGEMENT}

Sindhu Raveendran acknowledges Department of Science and Technology for sanctioning a project under DST-WOS-B scheme. Aravind Madhavan acknowledges Department of Biotechnology for Research Associateship. Anil Kuruvilla Mathew acknowledges Kerala Biotechnology Commission for Postdoctoral Fellowship. Amith Abraham acknowledges KSCSTE for Postdoctoral Fellowship. Sharrel Rebello acknowledges SERB for National Postdoctoral Fellowship.

\section{REFERENCES}

1. Soccol CR, Rojan PJ, Patel AK, Woiciechowski AL, Vandenberghe LPS, Pandey A. Glucoamylase. In: Pandey A, Webb C, Soccol CR, Larroche C, editors. Enzyme Technology. New Delhi, India: Asiatech Publishers Inc; 2005. pp. 221-38.

2. Gurung N, Ray S, Bose S, Rai V. A broader view: Microbial enzymes and their relevance in industries, medicine, and beyond. BioMed Res Int. 2013;(2013):Article ID 329121. https://doi.org/10.1155/2013/329121

3. Pandey A, Nigam P, Soccol CR, Soccol VT, Singh D, Mohan R. Advances in microbial amylases. Biotechnol Appl Biochem. 2000;31 (Pt 2):135-52.

4. de Souza PM, e Magalhães PO. Application of microbial a-amylase in industry - A review. Braz J Microbiol. 2010;41(4):850-61. https://doi.org/10.1590/S1517-83822010000400004

5. Rodríguez Couto S, Ángeles Sanromán M. Application of solid-state fermentation to food industry - A review. J Food Eng. 2006;76(3):291-302. https://doi.org/10.1016/j.jfoodeng.2005.05.022

6. van der Maarel MJEC, van der Veen B, Uitdehaag JCM, Leemhuis H, Dijkhuizen L. Properties and applications of starch-converting enzymes of the a-amylase family. J Biotechnol. 2002;94:137-55.

https://doi.org/10.1016/S0168-1656(01)00407-2
7. Aiyer PV. Amylases and their applications. Afr J Biotechnol. 2005;4(13):1525-9.

8. Kumar S. Role of enzymes in fruit juice processing and its quality enhancement. Adv Appl Sci Res. 2015;6:114-24.

9. Blanco CA, Caballero I, Barrios R, Rojas A. Innovations in the brewing industry: Light beer. Int J Food Sci Nutr. 2014;65:655-60 https://doi.org/10.3109/09637486.2014.893285

10. James J, Simpson BK, Marshall MR. Application of enzymes in food processing. Crit Rev Food Sci Nutr. 1996;36:437-63. https://doi.org/10.1080/10408399609527735

11. Aruna K, Shah J, Birmole R. Production and partial characterization of alkaline protease from Bacillus tequilensis strains CSGAB 0139 isolated from spoilt cottage cheese. Int J Appl Biol Pharm. 2014;5:201-21.

12. Miguel ÂSM, Martins-Meyer TS, Veríssimo da Costa Figueiredo E, Lobo BWP, Dellamora-Ortiz GM. Enzymes in bakery: Current and future trends. In: Muzzalupo I, editor. Food Industry. Rijeka, Croatia: InTech; 2013. https://doi.org/10.5772/53168

13. Zadow JG, editor. Whey and lactose processing. Dordrecht, The Netherlands: Springer; 1992.

https://doi.org/10.1007/978-94-011-2894-0

14. Gibson GR, Wang X. Regularory effects of bifidobacteria on the growth of other colonic bacteria. J Appl Bacteriol. 1994;77:412-20. https://doi.org/10.1111/j.1365-2672.1994.tb03443.x

15. Jooyendeh $\mathrm{H}$, Kaur A, Minhas KS. Lipases in dairy industry: A review. J Food Sci Tech. 2009;46(3):181-9.

16. Aravindan R, Anbumathi P, Viruthagiri T. Lipase applications in food industry. Indian J Biotechnol. 2007;6:141-58.

17. Law BA. Enzymes in dairy product manufacture. In: Van Oort M, Whitehurst RJ, editors. Enzymes in food technology. Oxford, UK: Wiley-Blackwell; 2009. pp. 88-102. https://doi.org/10.1002/9781444309935.ch5

18. Panda T, Gowrishankar BS. Production and applications of esterases. Appl Microbiol Biotechnol. 2005;67:160-9. https://doi.org/10.1007/s00253-004-1840-y

19. Faulds CB. What can feruloyl esterases do for us? Phytochem Rev. 2010;9:121-32. https://doi.org/10.1007/s11101-009-9156-2

20. Alvarez-Macarie E, Baratti J. Short chain flavour ester synthesis by a new esterase from Bacillus licheniformis. J Mol Catal B Enzym. 2000;10:377-83. https://doi.org/10.1016/S1381-1177(99)00109-5

21. Sukumaran RK, Singhania RR, Pandey A. Microbial cellulases - Production, applications and challenges. J Sci Ind Res. 2005;64:832-44.

22. Grassin C, Fauquembergue P. Fruit juices. In: Godfrey T, West S, editors. Industrial enzymology. London, UK: MacMillan Press; 1996. pp. 226-64. 
23. Camacho NA, Aguilar OG. Production, purification and characterization of a low-molecular-mass xylanase from Aspergillus sp. and its application in baking. Appl Biochem Biotechnol. 2003;104(3):159-72.

https://doi.org/10.1385/ABAB:104:3:159

24. Dervilly G, Leclercq C, Zimmerman D, Roue C, Thibault JF, Sauliner L. Isolation and characterization of high molar mass water-soluble arabinoxylans from barley and barley malt. Carbohydr Polym. 2002;47(2):143-9.

https://doi.org/10.1016/S0144-8617(01)00172-2

25. Pasha KM, Anuradha P, Subbarao D. Applications of pectinases in industrial sector. J Pure Appl Sci Technol. 2013;16:89-95.

26. Zhu Z, Momeu C, Zakhartsev M, Schwaneberg U. Making glucose oxidase fit for biofuel cell applications by directed protein evolution. Biosens Bioelectron. 2006;21:2046-51. https://doi.org/10.1016/j.bios.2005.11.018

27. Hanft F, Koehler P. Studies on the effect of glucose oxidase in bread making. J Sci Food Agric. 2006;86:1699-704. https://doi.org/10.1002/jsfa.2455

28. Tanrı̈̈ven D, Ekşi A. Phenolic compounds in pear juice from different cultivars. Food Chem. 2005;93:89-93. https://doi.org/10.1016/j.foodchem.2004.09.009

29. Labat $\mathrm{E}$, Morel MH, Rouau X. Effects of laccase and ferulic acid on wheat flour doughs. Cereal Chem. 2000;77:823-28. https://doi.org/10.1094/CCHEM.2000.77.6.823

30. Ough CS. Further investigations with glucose oxidase-catalase enzyme systems for use with wine. Am J Enol Vitic. 1975;26:30-6.

31. Sîrbu T. The searching of active catalase producers among the microscopic fungi. An Univ Oradea Fasc Biol. 2011;2:164-7.

32. Regaldo C, García-Almendárez BE, Duarte-Vázquez MA. Biotechnological applications of peroxidises. Phytochem Rev. 2004;3(1-2):243-56. https://doi.org/10.1023/B:PHYT.0000047797.81958.69

33. Choi EJ, Ahn HW, Kim WJ. Effect of a-acetolactate decarboxylase on diacetyl content of beer. Food Sci Biotechnol. 2015;24:1373-80.

https://doi.org/10.1007/s10068-015-0176-y

34. Mohan Kumar NS, Shimray CA, Indrani D, Manonmani HK. Reduction of acrylamide formation in sweet bread with L-asparaginase treatment. Food Bioprocess Tech. 2014;7:741-8.

https://doi.org/10.1007/s11947-013-1108-6

35. Zhu Y, Jia H, Xi M, Li J, Yang L, Li X. Characterization of a naringinase from Aspergillus oryzae 11250 and its application in the debitterization of orange juice. Process Biochem. 2017;62:114-21. https://doi.org/10.1016/j.procbio.2017.07.012

36. Gallego Custodio MV, Otamendi FP, Vidal DR, Vallés Alventosa S. Production and characterization of an Aspergillus terteus a-L-rhamnosidase of oenological interest. Z Lebensm Unters Forsch. 1996;203(6):522-7.

https://doi.org/10.1007/BF01193157

37. Sindhu R, Binod P, Madhavan A, Beevi US, Mathew AK, Abraham A, Pandey A, Kumar V. Molecular improvements in microbial a-amylases for enhanced stability and catalytic efficiency. Bioresour Technol. 2017;245(Part B):1740-8. https://doi.org/10.1016/j.biortech.2017.04.098

38. Sindhu R, Binod P, Pandey A. a-Amylases. In: Pandey A, Negi $S$, Soccol CR, editors. Current developments in biotechnology and bioengineering - Production, isolation and purification of industrial products. Amsterdam, the Netherlands: Elsevier B.V.; 2016. pp. 3-24. https://doi.org/10.1016/B978-0-444-63662-1.00001-4

39. Garg G, Singh A, Kaur A, Singh R, Kaur J, Mahajan R. Microbial pectinases: An ecofriendly tool of nature for industries. 3 Biotech. 2016;6:47. https://doi.org/10.1007/s13205-016-0371-4

40. Coutinho PM, Reilly PJ. Glucoamylase structural, functional and evolutionary relationships. Proteins. 1997;29(3):334-47. https://doi.org/10.1002/(SICI)1097-0134(199711) 29:3<334::AID-PROT7>3.0.CO;2-A

41. Singh R, Mittal A, Kumar M, Mehta PK. Microbial protease in commercial applications. J Pharm Chem Biol Sci. 2016;4(3):365-74.

42. Rao MB, Tanksale AM, Ghatge MS, Deshpande VV. Molecular and biotechnological aspects of microbial proteases. Microbiol Mol Biol Rev. 1998;62(3):597-635.

43. Li Q, Yi L, Marek P, Iverson BL. Commercial proteases: Present and future. FEBS Lett. 2013;587:1155-63.

https://doi.org/10.1016/j.febslet.2012.12.019

44. Patel NS, Fung SM, Zanichelli A, Cicardi M, Cohn JR. Ecallantide for treatment of acute attacks of acquired C1 esterase inhibitor deficiency. Allergy Asthma Proc. 2013;34(1):72-7. https://doi.org/10.2500/aap.2013.34.3620

45. Tucker GA, Woods LFJ, editors. Enzymes in food processing. Boston, MA, USA: Springer; 1995. https://doi.org/10.1007/978-1-4615-2147-1

46. Deng L, Wang Z, Yang S, Song J, Que F, Zhang H, Feng F. Improvement of functional properties of wheat gluten using acid protease from Aspergillus usamii. PLoS ONE. 2016;11:e0160101.

https://doi.org/10.1371/journal.pone.0160101

47. Enzymes for brewing and distilling. Nogent-sur-Seine, France: Soufflet Biotechnologies. Available from: https:// www.souffletbiotechnologies.com/wp-content/uploads/2017/11/BrewingDistilling.pdf.

48. Enzymes at work. Damhus T, Kaasgaard S, Olsen HS, editors. Bagsvaerd, Denmark: Novozymes A/S; 2013. Available from: https://mycourses.aalto.fi/pluginfile.php/102056/ mod_folder/content/0/Enzymes_at_work.pdf?forcedownload=1. 
49. Salleh AB, Razak CNA, Rahman RNZRA, Basri M. Protease introduction. In: Salleh AB, Rahman RNZRA, Basri M, editors. New lipases and proteases. New York, NY, USA: Nova Science Publishers, Inc; 2006. pp. 23-39.

50. Rosenberg ZMM. 2006. Current trends of $\beta$-galactosidase application in food technology. J Food Nutr Res. 2006;45(2):47-54.

51. Panesar PS, Kumari S, Panesar R. Potential applications of immobilized $\beta$-galactosidase in food processing industries. Enzyme Res. 2010;2010:Article ID 473137. https://doi.org/10.4061/2010/473137

52. Santos A, Ladero M, García-Ochoa F. Kinetic modeling of lactose hydrolysis by a $\beta$-galactosidase from Kluyveromyces fragilis. Enzyme Microb Technol. 1998;22:558-67. https://doi.org/10.1016/S0141-0229(97)00236-6

53. Boon MA, Janssen AEM, van't Riet K. Effect of temperature and enzyme origin on the enzymatic synthesis of oligosaccharides. Enzyme Microb Technol. 2000;26(2-4):271-81. https://doi.org/10.1016/S0141-0229(99)00167-2

54. Harju M. Lactose, its derivatives and their hydrolysis. Finn J Dairy Sci. 1991;49:1-47.

55. Jurado E, Camacho F, Luzón G, Vicaria JM. A new kinetic model proposed for enzymatic hydrolysis of lactose by a $\beta$-galactosidase from Kluyveromyces fragilis. Enzyme Microb Technol. 2002;31:300-9. https://doi.org/10.1016/S0141-0229(02)00107-2

56. Pivarnik LF, Senecal AG, Rand AG. Hydrolytic and transgalactosylic activities of commercial $\beta$-galactosidase (lactase) in food processing. Adv Food Nutr Res. 1995;38:1-102. https://doi.org/10.1016/S1043-4526(08)60083-2

57. Wołosowska S, Synowiecki J. Thermostable $\beta$-glucosidase with a broad substrate specificity suitable for processing of lactose-containing products. Food Chem. 2004;85:181-7. https://doi.org/10.1016/S0308-8146(03)00104-3

58. Shah NP, Spurgeon KR, Gilmore TM. Use of dry whey and lactose hydrolysis in yoghurt bases. Milchwissenschaft. 1993;48:494-8.

59. Khider K, Akretche DE, Larbot A. Purification of water effluent from a milk factory by ultrafiltration using Algerian clay support. Desalination 2004;167:147-51. https://doi.org/10.1016/j.desal.2004.06.123

60. Johansen AG, Vegarud GE, Skeie S. Seasonal and regional variation in the composition of whey from Norwegian Cheddar-type and Dutch-type cheeses. Int Dairy J. 2002;12:621-9. https://doi.org/10.1016/S0958-6946(02)00054-7

61. Fink CS, Hamosh P, Hamosh M. Fat digestion in the stomach: Stability of lingual lipase in the gastric environment. Pediatr Res. 1984;18(3):248-54. https://doi.org/10.1203/00006450-198403000-00006

62. Guerrand D. Lipases industrial applications: Focus on food and agroindustries. OCL. 2017;24:D403.

https://doi.org/10.1051/ocl/2017031
63. Gerits LR, Pareyt B, Decamps K, Delcour JA. Lipases and their functionality in the production of wheat-based food systems. Compr Rev Food Sci Food Saf. 2014;13(5):978-89. https://doi.org/10.1111/1541-4337.12085

64. Sharma R, Chisti Y, Banerjee UC. Production, purification, characterization and applications of lipases. Biotechnol Adv. 2001;19:627-62. https://doi.org/10.1016/S0734-9750(01)00086-6

65. Jaeger KE, Reetz MT. Microbial lipases form versatile tools for biotechnology. Trends Biotechnol. 1998;16:396-403. https://doi.org/10.1016/S0167-7799(98)01195-0

66. Colman MH, Macrae AR. Fat process and composition. UK patent 1577933. 1980.

67. Wei W, Wang R, Nie L, Yao S. Rapid determination of dimethoate with surface acoustic wave impedance sensor system. Anal Lett. 1997;30:2641-61. https://doi.org/10.1080/00032719708001811

68. Hasan F, Shah AA, Hameed A. Industrial applications of microbial lipases. Enzyme Microb Technol. 2006;39:235-51. https://doi.org/10.1016/j.enzmictec.2005.10.016

69. Ghosh PK, Saxena RK, Gupta R, Yadav RP, Davidson S. Microbial lipases: Production and applications. Sci Prog. 1996;79:119-57.

70. Borrelli GM, Trono D. Recombinant lipases and phospholipases and their use as biocatalysts for industrial applications. Int J Mol Sci. 2015;16(9):20774-840. https://doi.org/10.3390/ijms160920774

71. De Maria L, Vind J, Oxenbøll KM, Svendsen A, Patkar S. Phospholipases and their industrial applications. Appl Microbiol Biotechnol. 2007;74:290-300. https://doi.org/10.1007/s00253-006-0775-x

72. Zhao X, Shi-Jian D, Tao G, Xu R, Wang M, Reuhs B, Yang Y. Influence of phospholipase A2 (PLA2)-treated dried egg yolk on wheat dough rheological properties. LWT - Food Sci Technol. 2010;43(1):45-51. https://doi.org/10.1016/j.lwt.2009.06.027

73. Sirbu A, Paslaru V. Effect of lysomax formulation on rheological behavior of dough. J Agroaliment Proc Technol. 2006;12:199-208.

74. Cheng F, Sheng J, Cai T, Jin J, Liu W, Lin Y, et al. A protease-insensitive feruloyl esterase from China holstein cow rumen metagenomic library: Expression, characterization, and utilization in ferulic acid release from wheat straw. J Agric Food Chem. 2012;60:2546-53. https://doi.org/10.1021/jf204556u

75. Gallage NJ, Hansen EH, Kannangara R, Olsen CE, Motawia MS, Jørgensen K, et al. Vanillin formation from ferulic acid in Vanilla planifolia is catalysed by a single enzyme. Nat Commun. 2014;5:Article number 4037. https://doi.org/10.1038/ncomms5037

76. Xu Z, He H, Zhang S, GuoT, Kong J. Characterization of feruloylesterases produced by the four Lactobacillus species: 
L. amylovorus, L. acidophilus, L. farciminis and L. fermentum, isolated from ensiled corn stover. Front Microbiol. 2017;8:941.

https://doi.org/10.3389/fmicb.2017.00941

77. Guglielmetti S, De Noni I, Caracciolo F, Molinari F, Parini C, Mora D. Bacterial cinnamoyl esterase activity screening for the production of a novel functional food product. Appl Environ Microbiol. 2008;74:1284-8.

https://doi.org/10.1128/AEM.02093-07

78. Cumbee B, Hildebrand DF, Addo K. Soybean flour lipoxygenase isozymes effects on wheat flour dough rheological and bread making properties. J Food Sci. 1997;62(2):281-3. https://doi.org/10.1111/j.1365-2621.1997.tb03985.x

79. Koeduka T, Kajiwara T, Matsui K. Cloning of lipoxygenase genes from a cyanobacterium, Nostoc punctiforme, and its expression in Escherichia coli. Curr Microbiol. 2007;54:315-9. https://doi.org/10.1007/s00284-006-0512-9

80. Andreou AZ, Vanko M, Bezakova L, Feussner I. Properties of a mini 9R-lipoxygenase from Nostoc sp. PCC 7120 and its mutant forms. Phytochemistry. 2008;69:1832-7. https://doi.org/10.1016/j.phytochem.2008.03.002

81. Gao B, Boeglin WE, Zheng Y, Schneider C, Brash AR. Evidence for an ionic intermediate in the transformation of fatty acid hydroperoxide by a catalase-related allene oxide synthase from the cyanobacterium Acaryochloris marina. J Biol Chem. 2009;284:22087-98. https://doi.org/10.1074/jbc.M109.013151

82. Gao B, Boeglin WE, Brash AR. Omega-3 fatty acids are oxygenated at the $n-7$ carbon by the lipoxygenase domain of a fusion protein in the cyanobacterium Acaryochloris marina. Biochim Biophys Acta.

2010;1801:58-63.

https://doi.org/10.1016/j.bbalip.2009.09.004

83. McDonald CE. Lipoxygenase and lutein bleaching activity of durum wheat semolina. Cereal Chem. 1979;56:84-9.

84. Stauffer CE. Functional additives for bakery foods. New York, NY, USA: Springer; 1991.

85. Patel DD, Patel RR, Thakkar VR. Purification, characterization and application of lipoxygenase isoenzymes from Lasiodiplodia theobromae. Appl Biochem Biotechnol. 2015; 175(1):513-25.

https://doi.org/10.1007/s12010-014-1278-3

86. Hayward S, Cilliers T, Swart P. Lipoxygenases: From isolation to application. CRFSFS. 2017; 16:199-211.

https://doi.org/10.1111/1541-4337.12239

87. Schülein M. Cellulases of Trichoderma reesei. Methods Enzymol. 1988;160:234-42.

https://doi.org/10.1016/0076-6879(88)60125-X

88. Davies G, Henrissat B. Structures and mechanisms of glycosyl hydrolases. Structure. 1995;3:853-9. https://doi.org/10.1016/S0969-2126(01)00220-9

89. Kubicek CP. Systems biological approaches towards understanding cellulase production by Trichoderma reesei.
J Biotechnol. 2013;163:133-42.

https://doi.org/10.1016/j.jbiotec.2012.05.020

90. Payne CM, Knott BC, Mayes HB, Hansson H, Himmel $M E$, Sandgren $M$, et al. Fungal cellulases. Chem Rev. 2015;115:1308-48.

https://doi.org/10.1021/cr500351c

91. Naga Padma P, Sravani P, Mishra PN, Sneha N, Anuradha $K$. Synergestic effects of multiple enzymes on apple juice clarification. Ind J Sci Technol. 2017;10(10):1-5. https://doi.org/10.17485/ijst/2017/v10i10/107716

92. Leah R, Kigel J, Svendsen I, Mundy J. Biochemical and molecular characterization of a barley seed $\beta$-glucosidase. J Biol Chem. 1995;270:15789-97. https://doi.org/10.1074/jbc.270.26.15789

93. Kabir F, Sultana MS, Kurnianta H. Polyphenolic contents and antioxidant activities of underutilized grape (Vitis vinifera L.) pomace extracts. Prev Nutr Food Sci. 2015;20:210-4. https://doi.org/10.3746/pnf.2015.20.3.210

94. Humpf HU, Schreier P. Bound aroma compounds from the fruit and the leaves of blackberry (Rubus laciniata, L.). J Agric Food Chem. 1991;39:1830-2.

https://doi.org/10.1021/jf00010a028

95. Sajith S, Priji P, Sreedevi S, Benjamin S. An overview on fungal cellulases with an industrial perspective. J Nutr Food Sci. 2016;6(1):461.

https://doi.org/10.4172/2155-9600.1000461

96. Galante YM, Monteverdi R, Inama S, Caldini C, De Conti A, Lavelli V, Bonomi F. New applications of enzymes in wine making and olive oil production. Italian Biochem Soc Trans. 1993;4:34.

97. Bamforth CW. Current perspectives on the role of enzymes in brewing. J Cereal Sci. 2009;50(3):353-7. https://doi.org/10.1016/j.jcs.2009.03.001

98. Galante YM, DeConti A, Monteverdi R. Application of Trichoderma enzymes in food and feed industries. In: Harman GE, Kubicek CP, editors. Ganoderma and Gliocladium, vol. 2. Enzymes, biological control and commercial applications. London, UK: Taylor \& Francis Ltd; 1998. pp. 286-301.

99. Oksanen J, Ahvenainen J, Home S. Microbial cellulose for improving filterability of wort and beer. In: Proceedings of the 20th European Brewery Chemistry Congress, Helsinki, Finland: 1985. pp. 419-25.

100. Sukumaran RK. Bioethanol from lignocellulosic biomass, Part II. Production of cellulases and hemicellulases. In: Pandey A, editor. Handbook of plant-based biofuels. Boca Raton, FL, USA: CRC Press, Taylor \& Francis Group; 2009. pp. 141-57.

101. Collins T, Gerday C, Feller G. Xylanases, xylanase families and extremophilic xylanases. FEMS Microbiol Rev. 2005;29(1):3-23. https://doi.org/10.1016/j.femsre.2004.06.005

102. Sweeney MD, Xu F. Biomass converting enzymes as industrial biocatalysts for fuels and chemicals: Recent develop- 
ments. Catalysts. 2012;2:244-63.

https://doi.org/10.3390/catal2020244

103. Juturu V, Wu JC. Microbial exo-xylanases: A mini review. Appl Biochem Biotechnol. 2014;174:81-92.

https://doi.org/10.1007/s12010-014-1042-8

104. Sanghi A, Garg N, Gupta VK, Mittal A, Kuhad RC. One step purification and characterization of a cellulose free xylanase produced by alkalophilic Bacillus subtilis ASH. Braz J Microbiol. 2010;41:467-76.

https://doi.org/10.1590/S1517-83822010000200029

105. Bajaj BK, Singh NP. Production of xylanase from an alkali tolerant Streptomyces sp. 7b under solid-state fermentation, its purification, and characterization. Appl Biochem Biotechnol. 2010;162:1804-18.

https://doi.org/10.1007/s12010-010-8960-x

106. Sharma PK, Chand D. Production of cellulase free thermostable xylanase from Pseudomonas sp. XPB-6. Int Res J Biol Sci. 2012;1(5):31-41.

107. Nair SG, Sindhu R, Shashidhar S. Fungal xylanase production under solid state and submerged fermentation conditions. Afr J Microbiol Res. 2008;2:82-6.

108. Mandal A. Review on microbial xylanases and their applications. Int J Life Sci. 2015;4:178-87.

109. Martínez-Anaya MA, Jiménez T. Functionality of enzymes that hydrolyse starch and non-starch polysaccharide in breadmaking. Z Lebensm Unters Forsch. 1997;205(3):209-14. https://doi.org/10.1007/s002170050152

110. Polizeli MLTM, Rizzatti ACS, Monti R, Terezni HF, Jorge JA, Amorim DS. Xylanases from fungi: Properties and industrial applications. Appl Microbiol Biotechnol. 2005;67:577-91. https://doi.org/10.1007/s00253-005-1904-7

111. Saadoun I, Dawagreh A, Jaradat Z, Ababneh Q. Influence of culture conditions on pectinase production by Streptomyces sp. (strain J9). Int J Life Sci Med Res. 2013;3:148. https://doi.org/10.5963/LSMR0304002

112. Rebello S, Anju M, Aneesh EM, Sindhu R, Binod P, Pandey A. Recent advancements in the production and application of microbial pectinases: An overview. Rev Environ Sci Biotechnol. 2017;16:381-94.

https://doi.org/10.1007/s11157-017-9437-y

113. Pedrolli DB, Monteiro AC, Gomes E, Cano Carmona E. Pectin and pectinases: Production, characterization and industrial application of microbial pectinolytic enzymes. Open Biotechnol J. 2009;3:9-18.

https://doi.org/10.2174/1874070700903010009

114. Tapre AR, Jain RK. Pectinases: Enzymes for fruit processing industry. Int Food Res J. 2014;21:447-53.

115. Müller D. Studies on the new enzyme glucose oxidase. I. Biochem Z. 1928;199:136-70 (in German).

116. EL-Sherbeny GA, Shindia AA, SheriffYMM. Optimization of various factors affecting glucose oxidase activity produced by Aspergillus niger. Int J Agric Biol. 2005;7:953-8.
117. Kona RP, Qureshi N, Pai JS. Production of glucose oxidase using Aspergillus niger and corn steep liquor. Bioresour Technol. 2001;78:123-6.

https://doi.org/10.1016/S0960-8524(01)00014-1

118. Mikhailova RV, Shishko ZhF, Yasenko MI, Lobanok AG. Effect of culture conditions on extracellular glucose oxidase production by Penicillium adametzii strain BIM-90. Mikol Fitopatol. 2000;34:48-53.

119. Ramachandran S, Fontanille P, Pandey A, Larroche C. Gluconic acid: Properties, applications and microbial production. Food Technol Biotechnol. 2006;44:185-95.

120. Giardina P, Faraco V, Pezzella C, Piscitelli A, Vanhulle S, Sannia G. Laccases: A never-ending story. Cell Mol Life Sci. 2010; 67:369-85. https://doi.org/10.1007/s00018-009-0169-1

121. Madhavi V, Lele SS. Laccase: Properties and applications. Bioresources. 2009;4:1694-717.

122. Morozova OV, Shumakovich GP, Shleev SV, Yaropolov YI. Laccase-mediator systems and their applications: A review. Appl Biochem Microbiol. 2007;43(5):523-35. https://doi.org/10.1134/S0003683807050055

123. Gochev VK, Krastanov Al. Isolation of laccase producing Trichoderma sp. Bulg J Agric Sci. 2007;13:171-6.

124. Sadhasivam S, Savitha S, Swaminathan K, Lin FH. Production, purification and characterization of mid-redox potential laccase from a newly isolated Trichoderma harzianum WL1. Process Biochem. 2008;43:736-42. https://doi.org/10.1016/j.procbio.2008.02.017

125. Li G, Liu X, Yuan L. Improved laccase production by Funalia trogii in absorbent fermentation with nutrient carrier. J Biosci Bioeng. 2017;124(4):381-5.

https://doi.org/10.1016/j.jbiosc.2017.05.002

126. Tonin F, Melis R, Cordes A, Sanchez-Amat A, Pollegioni L, Rosini E. Comparison of different microbial laccases as tools for industrial uses. N Biotechnol. 2016;33(3):387-98. https://doi.org/10.1016/j.nbt.2016.01.007

127. Sun J, Zheng M, Lu Z, Lu F, Zhang C. Heterologous production of a temperature and $\mathrm{pH}$-stable laccase from Bacillus vallismortis FMB-103 in Escherichia coli and its application. Process Biochem. 2017;55:77-84. https://doi.org/10.1016/j.procbio.2017.01.030

128. Conrad LS, Sponholz WR, Berker O. Treatment of cork with a phenol oxidizing enzyme. US patent 6152966. 2000.

129. McMurrough I, Madigan D, Kelly R, O'Rourke T. Haze formation shelf-life prediction for lager beer. Food Technol. 1999;53:58-63.

130. Mathiasen TE. Laccase and beer storage. WO patent 1995021240A2. 1995.

131. Giovanelli G. Enzymic treatment of malt polyphenols for beer stabilization. Industrie delle Bevande. 1989;18:497502 (in Italian).

132. Pronk IMEJ, Leclercq C. Laccase from Myceliophthora thermophila expressed in Aspergillus oryzae. In:WHO Food ad- 
ditives series: 52. International Programme on Chemical Safety (IPCS) INCHEM; 2004. Available from: http://www. inchem.org/documents/jecfa/jecmono/v52je06.htm

133. Si JQ. Use of laccase in baking industry. US patent 6296883 B1. 1994.

134. Puri M, Sharma D, Barrow JC, Tiwary AK. Optimization of novel method for the extraction of steviosides from Stevia rebudiana leaves. Food Chem. 2012;132:1113-20. https://doi.org/10.1016/j.foodchem.2011.11.063

135. Singh RS, Sooch BS, Puri M. Optimization of medium and process parameters for the production of inulinase from a newly isolated Kluyveromyces marxianus YS-1. Bioresour Technol. 2007;98:2518-25.

https://doi.org/10.1016/j.biortech.2006.09.011

136. Wilkins TD, Wagner DL, Veltri Jr BJ, Gregory EM. Factors affecting the production of catalase by Bacteroides. J Clin Microbiol. 1978;8:553-7.

137. Frankenberg L, Brugna M, Hederstedt L. Enterococcus faecalis heme dependent catalase. J Bacteriol. 2002;184(22): 6351-6.

https://doi.org/10.1128/JB.184.22.6351-6356.2002

138. Gomaa OM, Momtaz AM. Characterization of the hydrogen peroxide tolerating 'Bacillus maroccanus' type strain isolated from textile wastewater. Arab J Biotechnol. 2006;9:83-94.

139. Amo T, Atomi H, Imanaka T. Unique presence of a manganese catalase in a hyperthermophilic archaeon, Pyrobaculum calidifontis VA1. J Bacteriol. 2002;184:3305-12. https://doi.org/10.1128/JB.184.12.3305-3312.2002

140. Oluoch KR, Welander U, Andersson MM, Mulaa FJ, Mattiasson B, Hatti-Kaul R. Hydrogen peroxide degradation by immobilized cells of alkaliphilic Bacillus halodurans. Biocatal Biotransform. 2006;24:215-22. https://doi.org/10.1080/10242420600662669

141. Calandrelli V, Gambacorta A, Romano I, Carratore V, Lama L. A novel thermo-alkali stable catalase-peroxidase from Oceanobacillus oncorhynchi subsp. incaldaniensis: Purification catalase production by regulation of carbon metabolism. World J Microbiol Biotechnol. 2008;24:2269-75. https://doi.org/10.1007/s11274-008-9741-3

142. Wang W, Sun M, Liu W, Zhang B. Purification and characterization of a psychrophilic catalase from Antarctic Bacillus. Can J Microbiol. 2008;54:823-8. https://doi.org/10.1139/w08-066

143. Nakayama M, Nakajima-Kambe T, Katayama H, Higuchi K, Kawasaki Y, Fuji R. High catalase production by Rhizobium radiobacter strain 2-1. J Biosci Bioeng. 2008;106:554-8. https://doi.org/10.1263/jbb.106.554

144. Bučková M, Godočíková J, Šimonovičová A, Polek B. Production of catalases by Aspergillus niger isolates as a response to pollutant stress by heavy metals. Curr Microbiol. 2005;50(4):175-9.

https://doi.org/10.1007/s00284-004-4458-5
145. Zeng HW, Cai YJ, Liao XR, Zhang F, Li YL, Zeng XK. Serratia marcescens SYBC08 catalase isolated from sludge containing hydrogen peroxide shows increased catalase production by regulation of carbon metabolism. Eng Life Sci. 2011;11:37-43.

https://doi.org/10.1002/elsc.201000115

146. Kimoto H, Yoshimune K, Matsuyma H, Yumoto I. Characterization of catalase from psychrotolerant Psychrobacter piscatorii T-3 exhibiting high catalase activity. Int J Mol Sci. 2012;13:1733-46.

https://doi.org/10.3390/ijms13021733

147. Morales Hernandez CE, Padilla Guerrero IE, Gonzalez Hernandez GA, Solis ES, Torres Guzman JC. Catalase over expression reduces the germination time and increases the pathogenicity of the fungus Metarhizium anisopliae. Appl Microbiol Biotechnol. 2010;87:1033-44.

https://doi.org/10.1007/s00253-010-2517-3

148. Röcker J, Schmitt M, Pasch L, Ebert K, Grossmann M. The use of glucose oxidase and catalase for the enzymatic reduction of the potential ethanol content in wine. Food Chem. 2016;210:660-70.

https://doi.org/10.1016/j.foodchem.2016.04.093

149. Hamid M, Khalil-ur-Rehman. Potential applications of peroxidases. Food Chem. 2009; 115:1177-86.

https://doi.org/10.1016/j.foodchem.2009.02.035

150. Wakamatsu K, Takahama U. Changes in peroxidase activity and in peroxidase isozymes in carrot callus. Physiol Plant. 1993;68:167-71.

https://doi.org/10.1111/j.1399-3054.1993.tb01774.x

151. Biles CL, Martyn RD. Peroxidase, polyphenol oxidase and shikimate dehydrogenase isozymes in relation to the tissue type, maturity and pathogen induction of watermelon seedlings. Plant Physiol Biochem. 1993;31(4):499-506.

152. Janusz G, Kucharzyk KH, Pawlik A, Staszczak M, Paszczynski AJ. Fungal laccase, manganese peroxidase and lignin peroxidase: Gene expression and regulation. Enzyme Microb Technol. 2013;52(1):1-12. https://doi.org/10.1016/j.enzmictec.2012.10.003

153. Conesa A, Punt PJ, van den Hondel CAMJJ. Fungal peroxidases: Molecular aspects and applications. J Biotechnol. 2002;93:143-58.

https://doi.org/10.1016/S0168-1656(01)00394-7

154. Colpa DI, Fraaije MW, van Bloois E. DyP-type peroxidases: A promising and versatile class of enzymes. J Ind Microbiol Biotechnol. 2014;41:1-7. https://doi.org/10.1007/s10295-013-1371-6

155. Brown ME, Chang MCY. Exploring bacterial lignin degradation. Curr Opin Chem Biol. 2014;19:1-7. https://doi.org/10.1016/j.cbpa.2013.11.015

156. Ventorino V, Aliberti A, Faraco V, Robertiello A, Giacobbe S, Ercolini $D$, et al. Exploring the microbiota dynamics related to vegetable biomasses degradation and study of lignocellulose-degrading bacteria for industrial biotechnological 
application. Sci Rep. 2015;5:8161.

https://doi.org/10.1038/srep08161

157. Majumdar S, Lukk T, Solbiati JO, Bauer S, Nair SK, Cronan JE, Gertl JA. Roles of small laccases from Streptomyces in lignin degradation. Biochemistry. 2014;53:4047-58. https://doi.org/10.1021/bi500285t

158. Ramachandra M, Crawford DL, Hertel G. Characterization of an extracellular lignin peroxidase of the lignocellulolytic actinomycete Streptomyces viridosporus. Appl Environ Microbiol. 1988;54(12):3057-63.

159. Holm KA. Automated determination of microbial peroxidase activity in fermentation samples using hydrogen peroxide as the substrate and 2,2'-azinobis(3-ethylbenzothiazoline-6-sulfonate) as the electron donor in a flow injection system. Analyst. 1995;120(8):2101-5.

https://doi.org/10.1039/AN9952002101

160. Bansal N, Kanwar SS. Peroxidase(s) in environment protection. ScientificWorldJournal. 2013;2013:Article ID 714639. https://doi.org/10.1155/2013/714639

161. Godtfredsen SE, Ottesen M. Maturation of beer with a-acetolactate decarboxylase. Carlsberg Res Commun. 1982;47(2):93-102.

https://doi.org/10.1007/BF02914029

162. Zhao C, Su H, Liu Y. Catalytic mechanism of acetolactate decarboxylase from Brevibacillus brevis towards both enantiomers of a-acetolactate. RSC Adv. 2016;6:80621-9. https://doi.org/10.1039/C6RA18264J

163. Dulieu C, Moll M, Boudrant J, Poncelet D. Improved performances and control of beer fermentation using encapsulated a-acetolactate decarboxylase and modeling. Biotechnol Prog. 2000;16:958-65.

https://doi.org/10.1021/bp000128k

164. Zhao F, Wang Q, Dong J, Xian M, Yu J, Yin H, et al. Enzyme-inorganic nanoflowers/alginate microbeads: An enzyme im- mobilization system and its potential application. Process Biochem. 2017;57:87-94.

https://doi.org/10.1016/j.procbio.2017.03.026

165. Krishnapura PR, Belur PD, Subramanya S. A critical review on properties and applications of microbial L-asparaginases. Crit Rev Microbiol. 2016;42:720-37. https://doi.org/10.3109/1040841X.2015.1022505

166. Puri M, Banerjee UC. Production, purification, and characterization of the debittering enzyme naringinase. Biotechnol Adv. 2000;18:207-17. https://doi.org/10.1016/S0734-9750(00)00034-3

167. Puri, M. Updates on naringinase: Structural and biotechnological aspects. Appl Microbiol Biotechnol. 2012;93:49-60. https://doi.org/10.1007/s00253-011-3679-3.

168. Busto MD, Meza V, Ortega N, Perez-Mateos M. Immobilization of naringinase from Aspergillus niger CECT 2088 in poly(vinyl alcohol) cryogels for the debittering of juices. Food Chem. 2007;104(3):1177-82.

https://doi.org/10.1016/j.foodchem.2007.01.033

169. Soares NFF, Hotchkiss JH. Naringinase immobilization in packaging films for reducing naringin concentration in grapefruit juice. J Food Sci. 1998;63(1):61-5.

https://doi.org/10.1111/j.1365-2621.1998.tb15676.x

170. Huang W, Zhan Y, Shi X, Chen J, Deng H, Du Y. Controllable immobilization of naringinase on electrospun cellulose acetate nanofibers and their application to juice debittering. Int J Biol Macromol. 2017;98:630-6.

https://doi.org/10.1016/j.ijbiomac.2017.02.018

171. Gong A, Zhu CT, Xu Y, Wang FQ, Tsabing DK, Wu FA, Wang J. Moving and unsinkable graphene sheets immobilized enzyme for microfluidic biocatalysis. Sci Rep. 2017;7:Article no. 4309.

https://doi.org/10.1038/s41598-017-04216-4 